\title{
PHYSICAL ACTIVITY AS A HEALTH NEED
}

\author{
Aleksander Olejnik, ${ }^{1, D}$ Zofia Kubińska, ${ }^{2, A, ~ B, ~ D ~ A n n a ~ P a n ́ c z u k, ~ 2, ~ B, ~ D ~ J o a n n a ~ K u b i n ́ s k a, ~ D ~}$ \\ ${ }^{1}$ I. Ya. Horbachevsky Ternopil State Medical University, Ukraine \\ 2 Pope John Paul II State School of Higher Education in Biała Podlaska, Poland \\ 3 John Paul II Catholic University of Lublin, Poland \\ A Study Design; ${ }^{\mathrm{B}}$ Data Collection; ${ }^{\mathrm{C}}$ Statistical Analysis; ${ }^{\mathrm{D}}$ Manuscript Preparation, ${ }^{\mathrm{E}}$ Funds Collection
}

\author{
Address for corpespondence: \\ Joanna Kubińska \\ John Paul II Catholic University of Lublin \\ Department of Physical Activity and Sport \\ Konstantynów 1G, 20-708 Lublin, Poland \\ E-mail: kubanna@kul.pl
}

\begin{abstract}
Ahstract The scientific concept of human needs has an interdisciplinary nature and is associated with the standards of living and development, health and disease status, quality of life, and life satisfaction. Research results indicate that systematic physical activity at any ontogenesis period is of vital importance for optimal development and maintenance of physical efficiency, fitness, and health. Therefore, it has been assumed that physical activity is a health need of each man. The aim of the study is to find relationships between physical activity and health needs. The analysis was intended to reveal the importance, functions, and consequences of the impact of physical activity on the psychophysical condition of man based on examples from available literature. The relationships between physical activity and health needs have been presented from the perspective of public health and promotion targeted at improvement of public health in a way to ensure the best fulfilment of conscious and unconscious needs.

According to WHO, health needs are disturbances in the health status or social well-being that require intervention measures such as treatment, rehabilitation, or social assistance as well as prevention measures. Systematic moderate physical activity is one of the most important factors with a beneficial effect on human physiological processes and improves the quality of life. The National Health Programme for 2016-2020 recommends increased physical activity among children, adolescents, and the elderly.
\end{abstract}

Key WOrlds human needs, health needs, physical activity

\section{Introduction}

The effective information of the society, in every stage of ontogenesis, about a negative influence of the sedentary life style and a positive influence of physical activity on the health, is now a main task of health promotion and education (Jethon, 2013; Kasperczyk, 2000). It requires a support by the scientific research of experts, results of epidemiological studies and recommendations of World Health Organization (2010), as well, as by European and national strategies elaborated on their basis. A model, scientific concept, according to which the components of physical fitness make a health basis and can be advantageously modified by a systematically undertaken physical effort, is a concept of HRF (Health Related Fitness), defined by the Toronto model, elaborated by Bouchard, 
Shepherd (1994). According to Jethon (2013), there is usually assumed, that a moderately intensive endurance training is the greatest health promotion and prevents different risk factors. Recently emphasized is, that other forms of exercise may be useful in health promotion. The great significance of physical activity for health, however, didn't acquire a proper rank of a necessary (conditio sine qua non) factor. That's why undertaken was an attempt of introduction of the physical activity as a health need. In the authors' opinion, it can contribute to its proper valuation. Currently the physical activity, because of its health advantages, is undertaken in Poland by only $12.3 \%$ of women and $7.4 \%$ of men (GUS, 2013).

Man is a creature with the ability to move, and systematic physical activity in each ontogenesis stage is essential for optimal development and maintenance of physical efficiency, fitness, and health. Therefore, it has been assumed that physical activity is very important health need in the life of every man.

The aim of the study is to find the relationships between physical activity and health needs. The analysis was intended to reveal the importance, functions, and consequences of the impact of physical activity on the psychophysical condition of man based on examples from available literature. The relationships between physical activity and health needs have been presented from the perspective of public health and promotion targeted at improvement of public health in a way to ensure the best fulfilment of conscious and unconscious social needs (Włodarczyk, 2007).

\section{Health needls}

In the usual sense, a need in human life always appears at the absence of something. The scientific notion of a need has an interdisciplinary character and is associated with standards of living and development, health and disease status, welfare, quality of life, and life satisfaction (Tobiasz-Adamczyk, 1996). The multidimensionality of needs is usually presented in terms of biology, psychology, sociology, economy, management, and medicine. In psychology, a need is referred to as a permanent condition of balance and development of a living organism, whereas a situation in which certain conditions are not fulfilled is termed deprivation of needs. A need is an objective phenomenon, and a man has as many needs as the number of conditions that have to be fulfilled to ensure development and reproduction (Reykowski, 1970). The hierarchical system of life needs developed by Maslov distinguishes basic needs and higher-order needs, which are activated when the basic needs are satisfied. Fulfilment of needs in the individual (biopsychic) and collective (social) dimensions is aimed at e.g. prevention of dysfunction in the performance of specific social roles, survival, personal development, and human freedom (Bednarz, 2008).

According to $\mathrm{WHO}$, health needs are disturbances in the health status or social well-being that require intervention measures such as treatment, rehabilitation, or social assistance as well as prevention measures (Topór-Mądry, Gilis-Januszewska, Kurkiewicz, Pająk, 2002).

According to Maslov's concept, basic and higher-order life needs are characterised by the following correlations: failure to satisfy the needs results in diseases, fulfilment of the needs prevents diseases, and restoration of the needs eliminates diseases. Additionally, the needs are inactive and not perceived by a healthy person (Topór-Mądry et al., 2002). As suggested by Michalak (2011), the most general definition of health needs in social sciences describes them as deviations in the health of the patient or his environment, which require necessary steps to prevent adverse health effects. From the point of view of the healthcare staff-patient relationship, health needs are divided into expressed needs, i.e. reported by the patient spontaneously, and unexpressed needs, both conscious (known but not reported by the individual) and unconscious (not realised by the individual and 
therefore not reported). This approach to needs renders them as a factor motivating individuals to undertake certain health-related behaviour, a rationale for taking certain actions, a criterion for allocation of healthcare resources, and a criterion of the rationality and legitimacy of the objectives of healthcare. From the organisational and economic point of view, health needs have been divided into real needs estimated based on epidemiological and demographic data, expressed needs related to individual and public expectations, and needs that have been satisfied by healthcare (Janaszczyk et al., 2012). The studies reported by Topór-Mądry et al. (2002) and Zarzeczna-Baran (2010) present four types of needs proposed by Bradshaw's classification of health needs. These include a normative need defined by experts or doctors as a need in a specific situation that can serve for comparison of desired and actual situations, felt need identified with a wish for specific health services, expressed need, i.e. a felt need turned into action, and comparative need, which can be important for allocation of healthcare resources. The concept of health needs related to the health status is usually associated with actions pertaining to the healthcare system, and the term "health needs" is used to describe needs expressed by individuals and addressed to the healthcare system. However, this narrow approach to health needs allows regarding them as factors and criteria of health (Zarzeczna-Baran, 2010). As suggested by Leowski (2008), all countries of the world are aware of the inevitability of the systematic growth of real and expressed health needs, which are determined by demographic and epidemiological transformations of society. The most important determinant of the increase in health needs and healthcare costs in medicine is the technological and biotechnological progress. It is bound mainly to increase expressed social needs within a short time.

\section{The term of physical activity and its relation with health, according to the point of view of the selected authors}

In literature, physical activity is defined and described in various ways. Drygas, Piotrowicz, Jegier, Kopeć, Podolec (2010), defines it as any body movement necessary for daily life or part of a workout program. The concept of physical activity is often used interchangeably with the term physical exercise. In the English-language definition proposed by Caspersen, Powell, Christenson (1985, p. 126), physical activity is defined as "any bodily movement produced by skeletal muscles that results in energy expenditure". According to Woynarowska (2010), physical activity can be defined as a physical load (work of skeletal muscles accompanied by various functional changes in the organism, exercise, and energy expenditure) imposed on individuals in everyday life, school, work, play, and organised physical exercise. It is also reasonable to define physical activity as an essential component of lifestyle, i.e. health-related behaviour (Bejnarowicz, 1995; Woynarowska, 2008). Health-related behaviour is represented by all forms of targeted activity leading to protection or improvement of individual's health. Many of such activities are associated with personal responsibility and care for health, which are independent of current healthcare systems (Majchrowska, 2003; Słopiecka, Cieślik, 2011; Syrek, 2000).

As suggested by Biernat (2011), scientific discussion about the importance of physical activity for health was started in the fifties by studies conducted by Morris et al., who demonstrated correlations between the development of diseases and a sedentary lifestyle. Successive studies confirmed the impact of physical inactivity on many other chronic diseases. Physical activity was appreciated as early as by physicians in ancient Greece. Hippocrates (460$377 \mathrm{BC}$ ) regarded dietetics and gymnastics as the major fundamentals of medicine. He was the first to describe the application of cold, sun heat, light, and physical exercise in medical therapy. In his work "Ars Parva", Galen (130200 AD) described the positive impact of movement on the development of the body; he also presented the types 
and methods of exercise and systematised posture defects. Forerunners of treatment with physical activity can be found among Polish physicians, e.g. Wojciech Oczko (1537-1600), Stefan Batory's doctor and the father of Polish balneology, or Sebastian Petrycy of Pilzno (1554-1626), a distinguished physician, philosopher, and professor at Kraków University, who strongly recommended physical exercises, playing ball, and walks (Brzeziński, 2000).

Moderate physical activity that is recommended currently by experts, i.e. physical exercise causing a slightly increased breathing rate and a slightly accelerated heart rate, has health effects on the organism. This type of activity is perceived subjectively as pleasant and not strenuous. The energy expenditure related to this type of exercise does not exceed 4-6 MET [Metabolic Equivalent - amount of oxygen in inhaled air $\left(\mathrm{VO}_{2}\right)$ at rest and utilised by the organism] (Drygas et al., 2010). Intense physical activity denotes a heavy effort leading to a substantially increased breathing rate (and an accelerated heart rate). As reported by Rutkowska (2012), already 150 years ago physicians in Poland not only appreciated but also postulated precise doses of physical activity. The author mentions the basic functions of physical activity described by theorists of physical education. The stimulatory function considerably stimulates development in childhood and adolescence, maintains the level of efficiency and performance in adulthood, and mitigates the effects of involutional changes in old age. Adaptive function adjusts organisms to environmental requirements and exercise (habituation) in adolescence and to the specificity of professional work in adulthood. Compensatory and corrective functions are stimuli balancing the effects of inactivity and one-sided overload of the organisms in every stage of life. As indicated by Woynarowska (2010), physical activity plays a preventive role in development of health disorders (obesity, atherosclerosis, arterial pressure) and has a therapeutic function in treatment of many conditions, including obesity, diabetes, asthma, cerebral palsy, and disorders of the musculoskeletal system.

As suggested by Drygas et al. (2010), the positive effect of exercise on organism functions in the elderly and on the successful ageing phenomenon should not be underestimated. Regular physical activity has a beneficial effect on mental alertness and prevents memory impairment. In another study, the author emphasises that physical exercise is a protective factor independent of the genetic background and other biological and socio-economic risk factors. Physical activity is useful in the prophylaxis and treatment of many age-related diseases (coronary artery disease, hypertension, obesity, hypercholesterolemia, diabetes, and osteoporosis) (Gray, Di Brezzo, Fort, 2013; Kopiczko, Wierzbicka, 2014; Kostka, 2010; Saravi, Sayegh, 2013; Sygit, 2015). The results of investigations conducted by Kostka (2010) confirm that physical activity is the most potent determinant preventing disability and one of the most important factors mitigating the impact of age on health. The author has found that physical exercise can be regarded as a common element in all prevention and rehabilitation activities, regardless of the elderly patient's health status and fitness.

The prophylactic and therapeutic efficacy of physical activity, repeatedly supported empirically, initiated an American program (American College of Sports Medicine, American Medical Association) Exercise is Medicine (EIM). Since 2007, in line with the strategy of the EIM program, physical activity has been part of practice aimed at prevention, alleviation of symptoms, and treatment of chronic diseases as well as improvement of the quality of life in over 40 countries in the world (Berryman, 2010; Lobelo, Stoutenberg, Hutber, 2014; Tipton, 2014). The EIM program is being increasingly popularised in Poland by two forerunners from the foundation "Zaskoczeni wiekiem" [Surprised with age]: doctor Plucik-Mrożek and fitness instructor Perl. The combination of medicine and fitness has yielded a new trend referred to as medical trend, which is focused on prevention of lifestyle diseases by promotion of physical activity and healthy lifestyle. This is important for individuals affected by health problems who want to feel 
good despite the disease. Thanks to the combined work of coaches, physicians, and dieticians, the program offers professional care of health and psychophysical status. Medical fitness activates patients with chronic diseases in a safe and conscious manner. Who can claim that a patient with cardiovascular and heart diseases or type 2 diabetes, obesity, or cancer should not be physically active? (Plucik-Mrożek, Perl, 2016).

The "Healthy People 2010" initiative of the US Department of Health and Human Services has established a list of 10 indicators for assessment of the population health status for the decade 2010-2020. Physical activity has been identified as the first of the five determinants of health. Experts recommend 20 -minute physical exercise at least 3 times a week to adolescents and 30-minute daily physical activity to adults (National Center for Health Statistics, 2012). As shown by the results of analyses of the indicators of the quality of primary healthcare and health needs performed by a group of experts from 9 OECD countries, physical activity has been classified in the health promotion group together with five other indicators (Marshall et al., 2006).

Since the beginning of the $90 \mathrm{~s}$, each edition of the National Health Programme (NHP) in Poland has emphasised the importance of the educational and practical impact of physical activity as an operational target. The program for 2016-2020 stresses the need for taking action to increase physical activity in society. It emphasises that physical activity is important throughout the lifetime; however, its role in prevention of overweight and obesity among children and adolescents and in old-age prophylaxis justify the concern about these two age groups (Narodowy Program Zdrowia na lata 2016-2020). The NHP guidelines are included in provincial and local government reports on the health status and are a basis for mapping health needs. The latest report on the health status and health needs of the inhabitants of Lublin Province, prepared for development of health policy programs for 2016-2021, defines health needs in two aspects: health impairment and actions undertaken to reduce or eliminate the problem. With its therapeutic-preventive effect, which can mitigate or eliminate identified health problems, physical activity has been included in 5 health programs, i.e. prevention of cardiovascular disease, reduction of the high incidence of cancer, early diagnosis of diabetes, maintenance of normal body weight, and prevention of the negative consequences of musculoskeletal diseases (Florek-Łuszczki et al., 2015).

\section{Summary}

The analysis of studies confirming positive relations of physical activities with health, according to selected authors, revealed also their method of describing it. It can be stated, that there is no unanimity in its naming. Different authors defined it as: gymnastics, mobility, physical effort, physical burden, the work of skeletal muscles, a component of a life style, health behavior, exercise, protective factors, preventive-rehabilitation activities, medical fitness, health determinant, medical-preventive action, health promoting physical activity, whereas according to Drygas et al. (2010) - an underestimated health factor. It must be pronounced, that those different terms show selected functions of physical activity, but also cause a certain dispersion. A contemporary man, determined by a sedentary and consuming life style, demands clear-cut terms, which names stimulate and bring an information about the social status of physical activity as a duty and necessity, contrary to some leisure time activities. Even the creators of the European health policy gave the high rank to the physical activities, emphasizing in the $2 n d$ Article of the European Union Council Recommendations, that the physical activity conditions the healthy life style and good health status of workers, contributes to achieving the main goals defined in the strategy "Europe 2020", especially in relation to economical growth, efficiency and health (Zalecenia Rady Unii Europejskiej, 2013). By way of conclusion of the information, it is reasonable to underline the relevance of the assumption that physical activity 
serving as an element of prevention, prophylaxis, therapy, and mitigation or elimination of health disturbances is a real and expressed need in the life of every man. However, knowledge of the health consequences of physical activity has no causal power and only minimally contributes to changes in the awareness and beliefs, stimulation of motivation, and minimisation of sedentary behaviour. Theoretical strategies of health policy-makers do not change the current situation, as they cannot overcome the barrier of financial resources. Similarly, the phenomenon of imposing individual commitment and responsibility for own health and that of other individuals, which was stressed in Poland during the transformation period, does not produce expected results. Various studies confirm that the educational and scientific activities in the realm of public health as well as promotion of health, physical culture, and medicine are not reflected in individual and public physical activity. Given the unsatisfactory epidemiological and demographic results, American and European experts offer an increasing, diverse range of health (prophylactic) programs, attractive individual activities, and available physical activity infrastructure. The decision to take up physical activity remains to be made by individuals.

\section{References}

Bednarz, M. (2008). Polityka społeczna jako zaspokajanie istotnych potrzeb społecznych. Bydgoszcz: Kujawsko-Pomorska Szkoła Wyższa w Bydgoszczy.

Bejnarowicz, J. (1995). Zmiany stylu życia i stanu zdrowia ludności Polski. In: Z. Czaplicki, W. Muzyka (ed.), Styl życia a zdrowie. Dylematy teorii i praktyki. Olsztyn: Polskie Towarzystwo Pedagogiczne.

Berryman, J.W. (2010). Exercise is medicine: a historical perspective. Curr Sport Med Rep, 9, 195-201.

Biernat, E. (2011). Aktywność fizyczna mieszkańców Warszawy na przykładzie wybranych grup zawodowych. Warszawa: Oficyna Wydawnicza Szkoła Główna Handlowa w Warszawie.

Bouchard, C., Shepard, R.J. (1994). Physical activity, fitness, and health: the model and key concepts. In: C. Bouchard, R.J. Shepard (eds.), Physical activity, fitness, and health (pp. 77-88). Champaign: Human Kinetics.

Brzeziński, T. (ed.) (2000). Historia medycyny. Warszawa: PZWL.

Caspersen, C.J., Powell, K.E., Christenson, G.M. (1985). Physical activity, exercise and Physical fitness: definitions for health-related research. Public. Health Rep., 100 (2), 126-131.

Drygas, W., Piotrowicz, R., Jegier, A., Kopeć, G., Podolec, P. (2010). Aktywność fizyczna u osób zdrowych. In: P. Podolec (ed.), Podręcznik Polskiego Forum Profilaktyki (vol. 2, pp. 437-446). Kraków: Medycyna Praktyczna.

Florek-Łuszczki, M., Lachowski, S., Kowalczyk-Bołtuć, J., Dziemidok, P., Jaworska, J., Tochman-Gawda, A., Szcześniak, G., Paprzycki, P., Janowska, A., Cisak, E., Wójcik-Fatla, A., Zając, V., Sawczyn, A., Kloc, A., Sroka, J., Dutkiewicz, J., Saran, T., Maruszewska, A., Bajor, I. (2015). Ocena stanu zdrowia oraz określenie potrzeb zdrowotnych mieszkańców województwa lubelskiego na potrzeby opracowywania programów polityki zdrowotnej realizowanych przez Samorząd Województwa Lubelskiego w latach 2016-2021. Lublin: Urząd Marszałkowski Województwa Lubelskiego. Retrieved from: http://www.lubelskie. pl/img/userfiles/files/Ocena.pdf.

Gray, M., Di Brezzo, R., Fort, I.L. (2013). The effects of power and strength training on bone mineral density in premenopausal women. J Sports Med Phys Fitness, 53 (4), 428-436.

GUS (2013). Uczestnictwo Polaków w sporcie i rekreacji ruchowej w 2012 r. Retrieved from: http://stat.gov.pl/cps/rde/xbcr/gus/KTS_ uczestnictwo_polakow_w_sporcie_2012.pdf (20.04.2017).

Janaszczyk, A., Sobczak, K., Gajewska, M., Leoniuk, K., Nowakowska, H., Zarzeczna-Baran, M., Wojdak-Haasa, E., Sut, P., Krakowiak, P. (2012). Główne pojęcia konstytuujące perspektywę filozoficzno-społeczną w naukach o zdrowiu. In: A. Janaszczyk, L. Wengler, P. Popowski, P. Pietrzak, I. Andrych-Brzezińska, E. Adamska-Pietrzak, K. Sobczak, E. Bandurska (eds.), Filozoficzne, społeczne i prawne aspekty nauk o zdrowiu. Cz. I. Filozoficzne i społeczne aspekty nauk o zdrowiu (pp. 12-67). Gdańsk: Polskie Towarzystwo Programów Zdrowotnych.

Jethon, Z. (2013). Physical activity as a distress. Hygeia Public Health, 48 (2), 156-161.

Kasperczyk, T. (2000). Poziom sprawności i aktywności fizycznej a zdrowie. Nowa Medycyna, 12. Retrieved from: http://www. czytelniamedyczna.pl/1609,poziom-sprawnosci-i-aktywnosci-fizycznej-a-zdrowie.html (20.04.2017) 
Kopiczko, A., Wierzbicka, E. (2014). Stan zmineralizowania tkanki kostnej kobiet uczęszczających na zajęcia fitness. Medycyna Rodzinna, 2, 54-58.

Kostka, T. (2010). Aktywność fizyczna u osób w podeszłym wieku. In: P. Podolec (ed.), Podręcznik Polskiego Forum Profilaktyki T. 2 (pp. 455-460). Kraków: Medycyna Praktyczna.

Leowski, J. (2008). Polityka zdrowotna a zdrowie publiczne. Warszawa: CeDeWu.

Lobelo, F., Stoutenberg, M., Hutber, A. (2014). The Exercise is Medicine Global Health Initiative: a 2014 update. Br J Sports Med, 48 , 1627-1633.

Majchrowska, A. (2003). Zachowania zdrowotne-aspekty socjologiczne. In: A. Majchrowska (ed.), Wybrane elementy socjologii (pp. 293-316). Lublin: Wydawnictwo Czelej.

Marshall, M., Klazinga, N., Leatherman, S., Hardy, C., Bergmann, E., Pisco, L., Mattke, S., Mainz, J. (2006). OECD Health Care Quality Indicator Project. The expert panel on primary care prevention and health promotion. Int. J. Qual. Health Care, 18, 21-25.

Michalak, J. (2011). Potrzeby zdrowotne a systemy zapewnienia jakości w opiece zdrowotnej. Studies \& Proceedings of Polish Association for Knowledge Management, 55, 52-61.

Narodowy Program Zdrowia na lata 2016-2020. In: Dziennik Ustaw Rzeczypospolitej Polskiej. Rozporządzenie Rady Ministrów z dnia 4 sierpnia 2016 r. w sprawie Narodowego Programu Zdrowia na lata 2016-2020.

National Center for Health Statistics (2012). Healthy People 2010 Final Review. Hyattsville, MD.

Plucik-Mrożek, A., Perl, M. (2016). Zaskoczeni wiekiem - wyćwicz swoje zdrowie. Retrieved from: http://zaskoczeni.com.pl/index.php/ fitness-medyczny.

Reykowski, J. (1970). Natura ludzka a potrzeby. Etyka, 6, 35-37.

Rutkowska, E. (2012). Ocena aktywności fizycznej w badaniach podmiotowych. Zamojskie Studia i Materiały. Fizjoterapia, 1 (35), 119-125.

Saraví, F.D., Sayegh, F. (2013). Bone Mineral Density and Body Composition of Adult Premenopausal Women with Three Levels of Physical Activity. Journal of Osteoporosis. DOI: 10.1155/2013/953271.

Słopiecka, A., Cieślik, A. (2011). Zachowania zdrowotne - wybrane definicje. Studia Medyczne, 24 (4), 77-82.

Sygit, K. (2015). Fundamental significance of physical activity for seniors' health. Central European Journal of Sport Sciences and Medicine, 12 (4), 53-59. DOI: 10.18276/cej.2015.4-06.

Syrek, E. (2000). Zdrowie w aspekcie pedagogiki społecznej. Katowice: Wydawnictwo Uniwersytetu Śląskiego.

Tipton, C.M. (2014). The history of "Exercise Is Medicine" in ancient civilizations. Advances in Physiology Education, 38 (2), $109-117$. DOI: 10.1152/advan.00136.2013.

Tobiasz-Adamczyk, B. (1996). Jakość życia w naukach społecznych i medycynie. Sztuka leczenia, 2, 33-40.

Topór-Mądry, R., Gilis-Januszewska, A., Kurkiewicz, J., Pająk, A. (2002). Szacowanie potrzeb zdrowotnych. Kraków: Vesalius.

Włodarczyk, C.W. (2007). Zdrowie publiczne w perspektywie międzynarodowej. Wybrane problemy. Kraków: Wydawnictwo Uniwersytetu Jagiellońskiego.

World Health Organization (2010). Global Recommendations on Physical activity for Health. Retrieved from: http://apps.who.int/iris/ bitstream/10665/44399/1/9789241599979_eng.pdf (20.04.2017).

Woynarowska, B. (2008). Edukacja prozdrowotna. Warszawa: Wydawnictwo Naukowe PWN.

Woynarowska, B. (2010). Aktywność fizyczna w dzieciństwie i młodości. In: P. Podolec (ed.), Podręcznik Polskiego Forum Profilaktyki T. 2 (pp. 461-466). Kraków: Medycyna Praktyczna.

Zalecenia Rady Unii Europejskiej z dnia 26 listopada 2013 r. w sprawie propagowania we wszystkich sektorach prozdrowotnej aktywności fizycznej (2013/C 354/01). Retrieved from: http://erasmusplus.org.pl/wp-content/uploads/2014/01/HEPA_Zalecenie_Rady.pdf (20.04.2017).

Zarzeczna-Baran, M. (2010). Potrzeby zdrowotne. Baza programów zdrowotnych województwa pomorskiego. Retrieved from: http:// ptpz.home.pl/bazaprogramow.zdrowiedlapomorzan.pl/public_html/upload/Potrzeby\%20zdrowotne.pdf (20.04.2017).

Cite this article aS: Olejnik, A., Kubińska, Z., Pańczuk, A., Kubińska, J. (2017). Physical Activity as a Health Need. Central European Journal of Sport Sciences and Medicine, 19 (3), 105-111. DOI: 10.18276/cej.2017.3-10. 
